\title{
PREZENTACJE
}

Ks. Stanisław Cieślak SJ

Wyższa Szkoła Filozoficzno-Pedagogiczna

„Ignacianum”, Kraków

\section{Jubileusz o. Ludwika Grzebienia SJ}

Dnia 10 czerwca 2010 r., podczas interdyscyplinarnej konferencji naukowej pt. Pamięć historyczna a edukacyjna teraźniejszość, Wyższa Szkoła Filozoficzno-Pedagogiczna Ignatianum w Krakowie uroczyście obchodziła 70. rocznicę urodzin jej rektora, o. prof. dr. hab. Ludwika Grzebienia SJ ${ }^{1}$. Warto poświęcić dostojnemu Jubilatowi nieco miejsca, albowiem należy On do wybitnych znawców dziejów Towarzystwa Jezusowego w Rzeczypospolitej, a swoim obszernym dorobkiem naukowym mógłby obdzielić niejednego naukowca.

O. Ludwik Jan Grzebień urodził się w rodzinie rolniczej Józefa i Anieli z d. Cyran, dwa tygodnie przed wybuchem II wojny światowej, w uroczystość Wniebowzięcia Najświętszej Maryi Panny 15 sierpnia 1939 r. w Tułkowicach k. Strzyżowa, poczta Wiśniowa, woje-

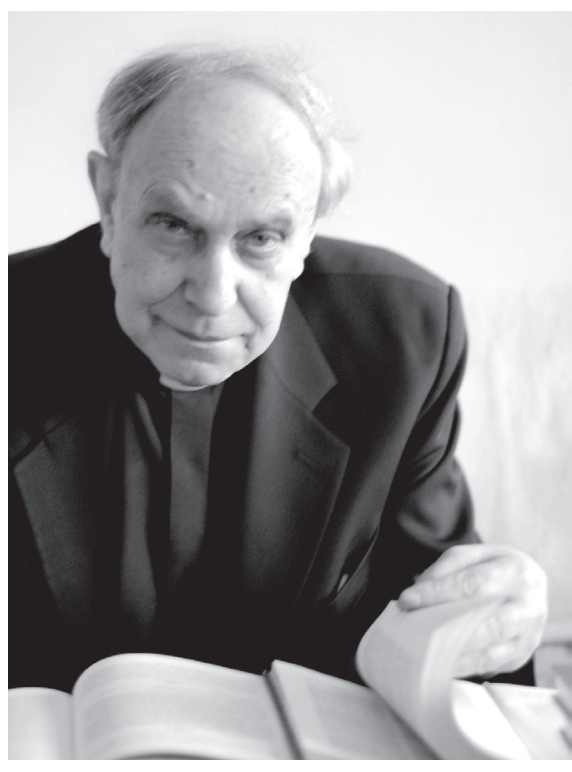
wództwo lwowskie (obecnie woj. podkarpackie). Sakrament chrztu oraz bierzmowania przyjął w swojej parafii pw. św. Stanisława Biskupa i Męczennika w Dobrzechowie, o której - wiele później - napisał monografię lokalną Dzieje parafii dobrzechowskiej, Kraków

${ }^{1}$ Dnia 18 VI 2009 r. uczelnia obchodziła jubileusz 70. rocznicy urodzin o. L. Grzebienia. Życzeniom towarzyszyła muzyka i śpiew zespołu Pefugium oraz kompozycja Magdy Hanausek. Jubilat otrzymał w prezencie swoją artystyczną podobiznę „Pavarotti Ignatianum”. 70. rocznica urodzin Rektora prof. dr. hab. Ludwika Grzebienia SJ, „Ignatianum” 2 (2009) (3), s. 9. 
1995. W Dobrzechowie ukończył siedem klas szkoły podstawowej, a następnie przez dwa lata uczył się w liceum w Czudcu, gdzie - dzięki dyrektorowi szkoły Władysławowi Woroszyńskiemu, który pożyczał mu przedwojenne książki, czasopisma, kalendarze - zaczęła się największa ze świeckich pasji Jubilata: książki i stare papiery².

Do Prowincji Małopolskiej Towarzystwa Jezusowego został przyjęty przez o. prowincjała Celestyna Szawana 18 sierpnia 1956 r. Dwuletni nowicjat odprawił w Starej Wsi k. Brzozowa pod kierunkiem byłego prowincjała o. magistra Wojciecha Krupy. Na zakończenie nowicjatu, 19 sierpnia 1958 r. w Starej Wsi, złożył pierwsze śluby zakonne na ręce o. Krupy ${ }^{3}$. Po nowicjacie pozostał w kolegium starowiejskim i pod okiem wybitnych profesorów jezuickich, z których niektórzy uczyli jeszcze przed II wojną światową w słynnym Zakładzie Naukowo-Wychowawczym w Chyrowie oraz konspiracyjnie podczas II wojny światowej w Starej Wsi, kontynuował naukę w zakresie szkoły średniej. Egzaminy kończące każdą klasę zdawał eksternistycznie w liceum dla pracujących w Krośnie. Ostatnią maturalną klasę zaliczył w Kaliszu, gdzie też zdał egzamin dojrzałości.

Na początku sierpnia 1958 r. napisał ze Starej Wsi list do redaktora czasopisma wewnątrzzakonnego „Wiadomości z Prowincji”, o. Andrzeja Bobera ${ }^{4}$. Do listu dołączył mały artykuł o 400. rocznicy pobytu św. Piotra Kanizego w Polsce z prośbą o jego publikację. O. Bober nie tylko przyjął artykuł do druku, ale także skreślił kilka zdań, wobec których młody jezuita nie mógł pozostać obojętny: Dając wyraz szczerej radości, że C[arissim] us od wczesnej młodości chwyta za pióro $i$ wykazuje $w$ tej dziedzinie budujacy zapat, zachęcam jednocześnie do rozczytywania się $w$ pracach dotyczacych jezuitów w Polsce. Wiele jest tu do zrobienia - czekamy zatem na nowych pracowników. Po przedwczesnej śmierci naszych czołowych historyków T[owarzystwa] J[ezusowego] w Polsce (oo. Bednarski ${ }^{5}$ i Poplatek ${ }^{6}$ ) przerzedzity się szeregi

2 R. Terlecki, Pasja historyka. Ojca Ludwika Grzebienia życie i praca, w: Pamięć wieków kształtuje potomność. Księga jubileuszowa dedykowana Księdzu Profesorowi Ludwikowi Grzebieniowi SJ z okazji 70. urodzin, red. A. P. Bieś, B. Topij-Stempińska, Kraków 2010, s. 17-18; Kwestionariusz osobisty członków Prowincji Galicyjskiej i Małopolskiej Towarzystwa Jezusowego, Archiwum Prowincji Polski Południowej Towarzystwa Jezusowego w Krakowie rkps 2434, s. 669 (dalej cyt.: ATJKr.).

3 Vota prima (1953-1963), ATJKr. rkps 1437, s. 132-134.

4 Bober Andrzej (1917-1986), m.in. profesor greki biblijnej na jezuickim Wydziale Teologicznym w Krakowie (1948-1949), patrystyki i archeologii chrześcijańskiej na Wydziale Teologii Bobolanum w Warszawie (1953-1958 i 1971-1980), seminariach diecezjalnych i w instytutach zakonnych w Krakowie, profesor patrologii na Katolickim Uniwersytecie Lubelskim (1971-1982). W latach 1956-1966 dyrektor Wydawnictwa Apostolstwa Modlitwy, a w latach 1966-1969 rektor w Krakowie. Wybitny patrolog. Encyklopedia wiedzy o jezuitach na ziemiach Polski $i$ Litwy 1564-1995, Kraków 1996, s. 50 (dalej cyt.: Encyklopedia wiedzy o jezuitach).

${ }^{5}$ Bednarski Stanisław (1896-1942), na jezuickim Wydziale Filozoficznym wykładał historię sztuki chrześcijańskiej i metodologię pracy naukowej. Od 1935 r. prokurator Wydawnictwa Apostolstwa Modlitwy, a od 1937 jego dyrektor. Wybitny znawca szkolnictwa i kultury jezuickiej. Zgromadził w Krakowie osobne archiwum fotokopii z Archivum Romanum Societatis Iesu (ARSI) i Archiwum Watykańskiego. Zmarł w obozie koncentracyjnym w Dachau. Sługa Boży. Encyklopedia wiedzy o jezuitach, s. 33-34.

${ }^{6}$ Poplatek Jan (1903-1955), profesor historii w Chyrowie (1930-1932 i 1937-1939). Podczas II wojny światowej superior we Lwowie i wiceprowincjał jezuitów pod okupacją rosyjską. Od 1945 pracował naukowo w Krakowie; kierował archiwum prowincji i wykładał metodologię pracy naukowej. Opracował wiele cennych monografii historycznych o jezuitach polskich. W rękopisie pozostawił dzieje prowincji podczas II wojny światowej, Encyklopedię jezuitów polskich XVI wieku oraz wiele innych prac. Stały współpracownik Polskiego słownika biograficznego. Encyklopedia wiedzy o jezuitach, s. 530. 
pracowników na tym polu. Oby Bóg zechciał przysłać nowych robotników na tę apostolska niwę! $!^{7}$

Po maturze studiował filozofię na Wydziale Filozoficznym Towarzystwa Jezusowego w Krakowie (1961-1964). Pod kierunkiem o. prof. Jana Popiela SJ napisał pracę licencjacką Filozofia Jana Bohomolca SJ. Następnie odbył studia teologiczne na Wydziale Teologicznym Bobolanum w Warszawie (1964-1968) ${ }^{8}$. Ukończył je pracą licencjacką Nieznane Estreicherom polonica w Bibliotece Teologicznej „Bobolanum”, której promotorem był o. prof. dr Marian Żurowski SJ. W Bobolanum pomagał w porządkowaniu biblioteki i wkrótce stał się wysokiej klasy bibliotekoznawcą ${ }^{9}$. Święcenia kapłańskie otrzymał 17 czerwca 1967 r. w Warszawie z rąk sługi Bożego, Prymasa Polski, ks. kard. Stefana Wyszyńskiego ${ }^{10}$.

Ostatni okres formacji zakonnej, zwany trzecią probacją i przewidziany przez św. Ignacego Loyolę przed złożeniem ostatnich ślubów, odbył pod kierunkiem doświadczonego instruktora o. Paula Kennedy SJ w St. Beauno’s College w Tremeirchion w północnej Walii (1 X 1973-24 V 1974) ${ }^{11}$. W czasie trzeciej probacji między innymi pracował wśród chorych oraz udzielił kilka serii rekolekcji dla Polonii. Podtrzymywał zapał naukowy i w wolnych chwilach odwiedzał archiwa angielskie ${ }^{12}$. Uroczystą profesję zakonną złożył na ręce asystenta Asystencji Słowiańskiej o. Petara Galaunera SJ 22 kwietnia 1977 r. w Starej Wsi k. Brzozowa ${ }^{13}$.

Po zakończeniu trzeciej probacji, na początku czerwca 1974 r., opuścił Anglię i wyruszył do Rzymu, gdzie zbadał w centralnym archiwum jezuickim (ARSI) materiały dotyczące misji zambijskiej ${ }^{14}$. Następnie z Rzymu udał się do Zambii, gdzie zebrał dalsze materiały dotyczące pracy jezuitów na misji ${ }^{15}$. Owocem jego wieloletniego zainteresowania problematyką misyjną, gromadzeniem materiałów archiwalnych oraz rozmów z żyją-

7 List. L. Grzebienia SJ do o. A. Bobera SJ, Stara Wieś, 3 VIII 1958 oraz List. o. A. Bobera SJ do L. Grzebienia SJ, Kraków, 4 IX 1958, w: Bober Andrzej SJ. Korespondencja od różnych osób z lat 1957-1983, ATJKr. rkps 4638, s. 402-403.

8 Sufragia examinum z teologii członków Towarzystwa Jezusowego z lat 1955/1956-1976/1977, ATJKr. rkps 4220 s. $137,150,157$.

9 R. Terlecki, Pasja historyka. Ojca Ludwika Grzebienia życie i praca, [w:] Pamięć wieków kształtuje potomność. Księga jubileuszowa dedykowana Księdzu Profesorowi Ludwikowi Grzebieniowi SJ z okazji 70. urodzin, s. 18-19.

${ }^{10}$ Kraków - Kuria Prowincjalska. Dokumenty dotyczące wyższych święceń członków Prowincji Małopolskiej Towarzystwa Jezusowego z lat 1933-1978, ATJKr. rkps 4225, s. 3-7, 9-10.

11 Korespondencja prowincjalska z lat 1969-1973, ATJKr. rkps 2285, s. 145, 151-153.

12 List. o. L. Grzebienia do o. prowincjała J. Popiela SJ, Tremeirchion, 13 IV 1974, w: Korespondencja prowincjalska za rok 1974, ATJKr. rkps 2915, s. 189; List. o. L. Grzebienia, Tremeirchion, 24 V 1974, w: ATJKr. rkps 2915, s. 191-199.

13 Liber admissorum II in Societatem Jesu z lat 1901-1975, ATJKr. rkps 4182, s. 189.

14 List. o. L. Grzebienia do o. prowincjała, Tremeirchion, 27 X 1973, w: Korespondencja prowincjalska z lat 1970-1973, ATJKr. rkps 2914, s. 293 oraz odpowiedź o. prowincjała J. Popiela SJ, Kłodzko, 11 XI 1973 , w: ATJKr. rkps 2914, s. 295.

W lecie 1974 r. zrobił kurs języka francuskiego w Besançon. Przy tej okazji odwiedził archiwum jezuickie w Tuluzie. List. o. L. Grzebienia do o. prowincjała J. Popiela SJ, Besançon, 25 VIII 1974, w: Korespondencja prowincjalska za rok 1974, ATJKr. rkps 2915, s. 201.

15 Korespondencja prowincjalska z lat 1969-1973, ATJKr. rkps 2285, s. 147-149. 
cymi misjonarzami zambijskimi, zwłaszcza z ks. arcybiskupem Adamem Kozłowieckim SJ (1911-2007), jest wiele publikacji (książek i artykułów), m.in. monografia Pionierski trud misjonarzy stowiańskich 1881-1969. Wśród ludu Zambii, t. 1, Kraków 1977. We wstępie do tej publikacji pisał: W pierwszym rzędzie monografia ma na celu złożenie hołdu dziesiątkom misjonarzy, którzy w pocie czoła, w bohaterskim niemal trudzie - szczególnie $w$ pionierskim okresie - właczali się w budowanie nowego społeczeństwa Zambii ${ }^{16}$. Przygotował również do druku listy ks. kard. Adama Kozłowieckiego SJ: Listy z misyjnego frontu, Kraków 1977. Dwadzieścia lat później opublikował je ponownie w nowym, poszerzonym wydaniu: Moja Afryka, moje Chingombe. Dzieje misjonarza opisane w listach do Przyjaciół, Kraków 1998.

Już w okresie studiów w zakonie podjął współpracę z wybitnym historykiem zakonu o. Bronisławem Natońskim SJ (1914-1989), gromadził materiały dotyczące dziejów jezuitów polskich, publikował artykuły oraz odwiedzał krajowe i zagraniczne archiwa i biblioteki ${ }^{17}$. W sierpniu 1968 r. udał się na kilka tygodni do Szwecji, gdzie spotkał się między innymi ze znawcą poloników w archiwach szwedzkich Józefem Trypućką (1910-1983), polskim językoznawcą i tłumaczem, od 1940 roku związanym z uniwersytetem w Uppsali. Podczas pobytu w Uppsali zapoznał się z rękopisami jezuickimi (m.in. korespondencją jezuitów z Braniewa i Poznania), które zrabowane z polskich kolegiów jezuickich trafiły do Szwecji oraz sprowadził do Krakowa szereg mikrofilmów poloników jezuickich ${ }^{18}$.

W 1975 r. przebywał przez jakiś czas u współbraci zakonnych w Chicago (USA). Także i tym razem była to wyprawa naukowa, z której przywiózł bratu Alojzemu Furczykowi SJ, kustoszowi Archiwum Prowincji Małopolskiej w Krakowie, między innymi materiały archiwalne dotyczące misji zambijskiej oraz brakujące w archiwum numery „Pionierskiego Trudu"19. W 1986 r. udał się ponownie do Stanów Zjednoczonych. Przez kilka tygodni pracował w bibliotece rezydencji jezuickiej w Chicago ${ }^{20}$. W sumie w celach naukowych sześć razy był w Szwecji, trzy razy odwiedził Stany Zjednoczone, raz Zambię oraz Australię.

We wrześniu 1968 r. został skierowany przez o. prowincjała Stanisława Nawrockiego na studia specjalistyczne do Lublina ${ }^{21}$. Tam studiował historię Kościoła (nauki pomocnicze historii) w Instytucie Historii Kościoła Katolickiego Uniwersytetu Lubelskiego (1968-1970). Na tej jedynej w całym obozie komunistycznym katolickiej uczelni szybko dał się poznać jako zdolny, pracowity i rokujący duże nadzieje na przyszłość student. Jednak on sam - jak podkreślał między innymi w liście do o. prowincjała Nawrockiego

${ }^{16}$ L. Grzebień, Pionierski trud misjonarzy słowiańskich 1881-1969. Wśród ludu Zambii, t. 1, Kraków 1977, s. 5.

17 Korespondencja z lat 1888-1971, ATJKr. rkps 2268, s. 173-183. Por. odpowiedź o. L. Grzebienia na ankietę o. T. M. McCooga SJ w sprawie Archiwum Prowincji Polski Południowej w Krakowie, Kraków, 19 III 1998, [w:] Różne pisma OO. Jezuitów, ATJKr. rkps 4947, s. 9, 16-17.

${ }_{18}$ List o. L. Grzebienia, Warszawa 3 X 1967, w: Korespondencja z lat 1888-1971, ATJKr. rkps 2268, s. 169; Korespondencja i dokumenty osobiste członków TJ z lat 1920-1969, ATJKr. rkps 2022, s. 551-573.

19 Majcher Walenty SJ. Korespondencja od różnych osób z lat 1958-1972, ATJKr. rkps 2826, s. 364.

${ }^{20}$ List. o. L. Grzebienia SJ do o. prowincjała B. Steczka SJ, Rzym, 13 I 1986, [w:] Korespondencja Ojca Prowincjała i Ojca Socjusza Prowincji. Rok 1986, ATJKr. rkps 4596, s. 64.

${ }^{21}$ Korespondencja prowincjalska z lat 1948-1968, ATJKr. rkps 2285, s. 141. 
- wiązał swoją przyszłość nie z Katolickim Uniwersytetem Lubelskim, ale z pracą naukową w bibliotekach i archiwum zakonnym w Krakowie ${ }^{22}$. Jednocześnie nigdy nie ukrywał, że solidną formację naukową zawdzięczał zarówno zakonowi, jak i Katolickiemu Uniwersytetowi Lubelskiemu.

W 1970 r. powrócił z Lublina do Krakowa i w kolegium pełnił między innymi obowiązki prefekta kleryków, zajmował się biblioteką prowincji, udzielał się duszpastersko w bazylice, pisał hasła do Encyklopedii Katolickiej KUL i artykuły naukowe, a także przygotowywał doktorat ${ }^{23}$.

Przez całe życie pracował z niezwykłym zapałem nad dziejami zakonu i jego wkładem do nauki i kultury Rzeczypospolitej. Nic dziwnego, że nie tylko szybko rosła jego bibliografia prac, ale także rytmicznym krokiem przemierzał kolejne stopnie kariery naukowej. W 1971 r. obronił pracę magisterską Biblioteka biskupa Hieronima Rozrażewskiego (1542-1600), którą napisał na seminarium ks. prof. dr. hab. Stanisława Librowskiego. Rok później przedstawił temu samemu promotorowi gotowy doktorat Organizacja bibliotek jezuickich w Polsce od XVI do XVIII wieku, którego recenzentami byli znani ze swej surowości ks. prof. dr hab. Bolesław Kumor z KUL oraz dr hab. Leszek Hajdukiewicz z Uniwersytetu Jagiellońskiego ${ }^{24}$. W 1978 r. na podstawie rozprawy Pionierski trud misjonarzy słowiańskich 1881-1969 uzyskał na Akademii Teologii Katolickiej (ATK) tytuł doktora habilitowanego teologii w zakresie historii Kościoła. Na ATK proponowano mu katedrę po o. prof. Hieronimie E. Wyczawskim OFM, ale propozycję odrzucił. W $1990 \mathrm{r}$. uzyskał kościelny tytuł profesora historii Kościoła (archiwistyka, źródłoznawstwo, bibliotekarstwo), zatwierdzony przez Centralną Komisję Kwalifikacyjną w 1999 r. ${ }^{25}$

Przez wiele lat uczył, jednak najbardziej cenił sobie pisarstwo i powiększanie bibliotecznych i archiwalnych zbiorów. Jako asystent pracował przy katedrze nauk pomocniczych historii Kościoła Katolickiego Uniwersytetu Lubelskiego (1972-1973). 30 czerwca 1973 r. otrzymał z rektoratu uczelni zawiadomienie o udzieleniu mu bezpłatnego urlopu okolicznościowego na okres od sierpnia 1973 do sierpnia 1974 r., którzy wykorzystał między innymi na trzecią probację w Anglii ${ }^{26}$. W latach 1979-1982 prowadził wykłady z zakresu historii Kościoła w Akademii Teologii Katolickiej w Warszawie. Od 1985 r.

${ }^{22}$ List o. L. Grzebienia, Lublin, 7 X 1968, w: Korespondencja i dokumenty osobiste członków TJ z lat 1920-1969, ATJKr. rkps 2022, s. 565; List o. L. Grzebienia do o. prowincjała S. Nawrockiego SJ, Lublin, 13 VI 1970, w: ATJKr. rkps 2266, Korespondencja prowincjalska za rok 1970, s. 175.

23 Survey 1970 - Ankieta imienna, ATJKr. rkps 4218, s. 66.

${ }^{24}$ R. Terlecki, Pasja historyka. Ojca Ludwika Grzebienia życie i praca, w: Pamięć wieków kształtuje potomność. Księga jubileuszowa dedykowana Księdzu Profesorowi Ludwikowi Grzebieniowi SJ z okazji 70. urodzin, s. 19.

${ }^{25}$ Warto dodać, że 12 XI 1987 rzymska Kongregacja do spraw Kształcenia Katolickiego przyznała mu tytuł profesora agregowanego (professor aggregatus) Wydziału Filozoficznego Towarzystwa Jezusowego w Krakowie. W myśl ustawy o tytułach i stopniach naukowych z 12 IX 1990 r. dotychczasowi profesorowi agregowani zostali automatycznie uznani na Wydziale za profesorów nadzwyczajnych. Korespondencja generalska z lat 1983-1989, ATJKr. rkps 4712, s. 119-121, 123; Korespondencja prowincjalska za lata 1990-1991, ATJKr. rkps 4769, s. 103; R. Darowski, Filozofia jezuitów w Polsce w XX wieku. Próba syntezy. Słownik autorów, Kraków 2001, s. 150.

${ }^{26}$ Korespondencja prowincjalska oraz do Ojca Socjusza Prowincji z lat 1963-1980, ATJKr. rkps 4213, s. $220-221$. 
wykładał metodologię i metodykę pracy naukowej na Wydziale Filozoficznym Towarzystwa Jezusowego w Krakowie (od 1999 r. Wyższa Szkoła Filozoficzno-Pedagogiczna Ignatianum).

Dnia 1 października 1988 r. władze zakonne powierzyły mu obowiązki dziekana Wydziału Filozoficznego Towarzystwa Jezusowego w Krakowie, które pełnił do 1994 r. ${ }^{27}$ Jako dziekan zabiegał o rozwój uczelni, która w czasach komunistycznych stanowiła studium domesticum zakonu, a po zmianach zainicjowanych przez NSZZ „Solidarność” i wyborach z 4 czerwca 1989 r. została otwarta także dla osób świeckich ${ }^{28}$. Dzięki między innymi Jego staraniom 19 grudnia 1990 r. rzymska Kongregacja do spraw Kształcenia Katolickiego zatwierdziła definitywnie statuty Wydziału Filozoficznego, dostosowane do państwowej Ustawy o tytule naukowym i stopniach naukowych z 12 września 1990 r. ${ }^{29}$

W 2004 r. został mianowany przez o. generała Petera-Hansa Kolvenbacha SJ rektorem Wyższej Szkoły Filozoficzno-Pedagogicznej Ignatianum. Podczas jego kadencji uczelnia uzyskała prawa do doktoryzowania dla Wydziału Pedagogicznego oraz dofinansowanie ze strony państwa. Otwarto nowe kierunki i specjalności oraz poszerzono grono profesorów i wykładowców. Podjęto także prace zmierzające do dalszej rozbudowy bazy materialnej. Pomimo różnych obowiązków rektorskich nie przerwał działalności badawczej i pisarskiej. Jest promotorem siedmiu rozpraw doktorskich i kilkudziesięciu prac magisterskich i licencjackich.

Dla całości obrazu rozległej działalności dydaktyczno-naukowej Jubilata dodajmy jeszcze, że od 1989 r. wykładał na Papieskiej Akademii Teologicznej w Krakowie, najpierw do 1995 r. na Wydziale Filozoficznym, a następnie do 2004 na Wydziale Historii Kościoła (obecnie Uniwersytet im. Jana Pawła II w Krakowie).

Od wielu lat jest związany z najstarszym w Polsce katolickim Wydawnictwem Apostolstwa Modlitwy w Krakowie, założonym w 1872 r. przez o. Stanisława Stojałowskiego SJ. W Wydawnictwie opublikował wiele wartościowych publikacji. Pod jego redakcją ukazały się drukiem między innymi dzieje Wydawnictwa: Wydawnictwo Apostolstwo Modlitwy 1872-1972. Historia, opracowania, bibliografia, Kraków 1972 (współredaktor Z. Wilkosz) oraz Wydawnictwo WAM 1972-1997. Historia, bibliografia, Kraków 1997 (współredaktor Z. Wilkosz) ${ }^{30}$. W okresie legalnej działalności NSZZ „Solidarność”, 27 czerwca 1981 r., o. prowincjał Eugeniusz Ożóg mianował go dyrektorem Wydawnictwa Apostolstwa Modlitwy ${ }^{31}$. Obowiązki te pełnił do 28 lutego 1985 r., a z dniem 1 czerwca tegoż roku objął stanowisko zastępcy naczelnego redaktora działu książkowego ${ }^{32}$. Jako dyrektor Wydawnictwa Apostolstwa Modlitwy walnie przyczynił się do jego rozwoju w niełatwym okresie stanu wojennego i napiętych relacji Kościół-państwo. Podejmował

27 Korespondencja generalska z lat 1983-1989, ATJKr. rkps 4712, s. 167-170, 189.

${ }^{28}$ Korespondencja prowincjalska z lat 1985-1989, ATJKr. rkps 4705, s. 79-80.

${ }^{29}$ Korespondencja prowincjalska za lata 1990-1991, ATJKr. rkps 4769, s. 103-104; Korespondencja prowincjalska z 1991 roku, ATJKr. rkps 4793, s. 53-55.

${ }^{30}$ Kraków - Kuria Prowincjalska. Publikacje Naszych 1966-1978, ATJKr. rkps 4593, s. 40.

${ }^{31}$ Korespondencja prowincjalska za rok 1981, ATJKr. rkps 4417, s. 104.

32 Korespondencja prowincjalska z lat 1984-1987, ATJKr. rkps 4606, s. 245. 
wysiłki u władz komunistycznych zmierzające do otrzymania pozwoleń na druk książek i czasopism oraz zabiegał o koncesję na zakład poligraficzny (drukarnię) ${ }^{33}$. Z Jego inicjatywy, i w dużej mierze dzięki Jego usilnym zabiegom prowadzonym u władz zakonnych i państwowych, doszło do budowy domu wspólnoty zakonnej (tzw. Dom Pisarzy), w którym znalazły siedzibę także biura i drukarnia Wydawnictwa Apostolstwa Modlitwy oraz Biblioteka Naukowa.

W 1977 r. objął funkcję „,bibliotekarza Prowincji” po o. Henryku Frosie SJ. Jego głównym zadaniem była opieka nad Biblioteką Pisarzy (obecnie Naukową) Księży Jezuitów w Krakowie. W 1988 r. przeniósł jej zasoby zarówno te z kolegium, jak i spod Bazyliki Najświętszego Serca Pana Jezusa (zmagazynowane tam na skutek II wojny światowej) do nowego gmachu Wydawnictwa Apostolstwa Modlitwy, o który tak intensywnie zabiegał. Dyrektorem Biblioteki Naukowej był do 25 sierpnia 2002 r. ${ }^{34}$ Biblioteka posiada fotokopie i mikrofilmy z dokumentacją archiwalną i biblioteczną dotyczącą dziejów jezuitów w Polsce, gromadzone od przeszło 70 lat. Wiele z nich znalazło swoje miejsce w Bibliotece dzięki zabiegom o. Grzebienia, który prócz tego od 1988 roku jest także dyrektorem Archiwum Prowincji Polski Południowej Towarzystwa Jezusowego.

Jubilat zna bardzo dobrze biblioteki i archiwa jezuickie oraz państwowe. Jak już wspomniano w celach naukowych oraz wzbogacenia zasobów Archiwum Prowincji Polski Południowej w Krakowie wielokrotnie udawał się do centralnego archiwum zakonnego w Rzymie. Już w 1975 r. opublikował pracę doktorską Organizacja bibliotek jezuickich w Polsce od XVI do XVIII wieku, Lublin 1975. Wyniki wieloletnich badań zawarł także w publikacji zbiorowej pt. Polonica $w$ Archiwum Rzymskim Towarzystwa Jezusowego (t. 1-5, Kraków 2002-2008, seria: „Źródła do dziejów kultury”) oraz opracowaniu zatytułowanym Podstawowa bibliografia do dziejów Towarzystwa Jezusowego w Polsce (t. 1-2, Kraków 2009). Zainicjował także ważne dla dziejów Towarzystwa Jezusowego w Rzeczypospolitej Obojga Narodów serie wydawnicze: „Studia i materiały do dziejów jezuitów polskich” (od 1998 r.) oraz „Klasycy jezuickiej historiografii” (od 2002 roku).

Jednym z wymownych dowodów jego umiejętności współpracy z wieloma środowiskami naukowymi w Polsce jest dzieło Wkład jezuitów do nauki i kultury Rzeczypospolitej Obojga Narodów i pod zaborami, pod red. I. Stasiewicz-Jasiukowej, Wydawnictwo WAM, Kraków-Warszawa 2004, ss. 758. Publikacja ta powstała we współpracy Komitetu Historii Nauki i Techniki Polskiej Akademii Nauk oraz Wyższej Szkoły Filozoficzno-Pedagogicznej Ignatianum i - jak podkreśliła w słowie od redaktora naukowego pani prof. I. Stasiewicz-Jasiukowa - ma ona istotne znaczenie poznawcze i upowszechniajace, gdyż nie było dotad $w$ historiografii polskiej tak wielostronnego spojrzenia na naukowy doro-

${ }^{33}$ Korespondencja prowincjalska z lat 1979-1985, ATJKr. rkps 4485, s. 361-364.

${ }^{34}$ List. o. L. Grzebienia SJ do o. prowincjała B. Steczka SJ, Kraków, 11 V 1988, w: Korespondencja prowincjalska z lat 1985-1989, ATJKr. rkps 4705, s. 81; K. Woda, Biblioteka Naukowa Księży Jezuitów w Krakowie, w: Librorum amatori. Księga pamiątkowa ofiarowana ks. Czesławowi Michalunio SJ na 50-lecie ofiarnej pracy w Bibliotece Filozoficznej Towarzystwa Jezusowego w Krakowie, red. A. P. Bieś SJ, Kraków 2004, s. 84, 90-91; R. Darowski, Filozofia jezuitów w Polsce w XX wieku. Próba syntezy. Słownik autorów, s. 150. 
bek członków Towarzystwa Jezusowego ${ }^{35}$. O. Profesor Ludwik Grzebień SJ - pisała dalej pani prof. I. Stasiewicz-Jasiukowa - zyskał szczególną sympatię i uznanie Kolegów z Komitetu Historii Nauki i Techniki PAN oraz tych Współautorów książi, którym poświęcit wiele czasu, towarzyszac im w poszukiwaniach materiałów źródłowych znajdujacych się w Archiwum OO. Jezuitów w Krakowie ${ }^{36}$. Kontynuacją owocnej współpracy Komitetu Historii Nauki i Techniki Polskiej Akademii Nauk oraz Wyższej Szkoły Filozoficzno-Pedagogicznej Ignatianum jest kolejna publikacja pt. Wkład osiagnięć polskiej nauki i techniki do dziedzictwa światowego, pod red. I. Stasiewicz-Jasiukowej, Wydawnictwo WAM, Kraków-Warszawa 2009, ss. 400. Aby przybliżyć czytelnikowi zagranicznemu osiągnięcia polskiej nauki i techniki, publikacja ukaże się także w języku angielskim.

Przez wiele lat Jubilat zajmował się wyjątkowym w historii polskiego szkolnictwa Zakładem Naukowo-Wychowawczym w Chyrowie, elitarną szkołą męską, przeznaczoną głównie dla synów ziemian, urzędników państwowych i przedsiębiorców. Przez szkołę istniejącą w latach 1886-1939 przeszło ok. 6170 uczniów, trzy pokolenia polskiej inteligencji i ziemiaństwa, którzy zapisali się złotymi zgłoskami na kartach historii Polski. Warto wspomnieć, że przynajmniej 35 uczniów chyrowskich zostało zamordowanych w Katyniu, a 48 w Charkowie. Owocem jego wieloletnich i żmudnych badań na tym polu są książki: Chyrowiacy, Kraków 1990 oraz Chyrowiacy. Słownik biograficzny wychowanków Zakładu Naukowo-Wychowawczego OO. Jezuitów w Chyrowie, 1886-1939, Kraków 2000 (we współpracy z J. Kochanowiczem i J. Niemcem).

Jubilat współpracuje od pierwszego tomu z redakcją Encyklopedii Katolickiej KUL oraz od 1972 r. z redakcją Polskiego słownika biograficznego. Owocem tej współpracy jest wiele haseł jezuitów polskich, opracowanych na podstawie materiałów archiwalnych. Należy do grona rekordzistów w ilości napisanych biogramów do Polskiego Słownika Biograficznego. Był także redaktorem i współredaktorem cennego dla kultury narodowej Słownika polskich teologów katolickich, t. 5-7, Warszawa 1983. Tomy te obejmują teologów zmarłych w latach 1918-1981 i zawierają 873 przedstawicieli różnych dyscyplin teologicznych z tego okresu. O skali tego ostatniego przedsięwzięcia, które prowadził na różnych etapach, świadczy chociażby obfita korespondencja z autorami artykułów do słownika, zachowana w Archiwum Prowincji Polski Południowej Towarzystwa Jezusowego w Krakowie ${ }^{37}$. Na szczególną uwagę zasługuje pionierska, niezwykle wysoko oceniana przez uczonych Encyklopedia wiedzy o jezuitach na ziemiach Polski i Litwy 1564-1995, Kraków 1996, którą opracował przy współpracy zespołu jezuitów. Stanowi ona ewenement w skali światowej i może być wzorem dla innych zakonów. Encyklopedia jest nie tylko źródłem informacji do dziejów jezuitów na ziemiach Polski i Litwy w latach 1564-1995, ale także zawiera podstawową bibliografię dotyczącą zakonu w Polsce oraz podstawowe zasoby archiwalne jezuickie i obce obejmujące poszczególne problemy. Bez przesady

${ }^{35}$ Wkład jezuitów do nauki i kultury Rzeczypospolitej Obojga Narodów i pod zaborami, red. I. Stasiewicz-Jasiukowa, Kraków-Warszawa 2004, s. 5.

${ }^{36}$ Ibidem, s. 7.

37 Grzebień Ludwik SJ. Korespondencja z autorami artykułów do słownika polskich teologów katolickich, ATJKr. rkps 4422, s. 1-131. Zob. List o. L. Grzebienia do o. J. Pietruszki SJ, Kraków, 1 IX 1980, w: Pietruszka Józef SJ. Korespondencja z lat 1954-1984, ATJKr. rkps 4497, s. 40. 
można powiedzieć, że o. Grzebień stał się mistrzem w tworzeniu słowników biograficznych i publikacji encyklopedycznych. Są one Jego ulubioną formą pisarską oraz świadectwem niewiarygodnej wprost pracowitości.

Wyrazem jego zainteresowań okresem białoruskim oraz dziejami Prowincji Galicyjskiej Towarzystwa Jezusowego, w którym nie brak wątków polskich, jest książka Burzliwe lata Polonii amerykańskiej. Wspomnienia i listy misjonarzy jezuickich 1864-1913, Kraków 1983. Publikacja zawierająca listy i pamiętniki wyjęte z rękopisów 12 misjonarzy i to najbardziej znanych na polu misyjnym, ukazuje więź Kościoła katolickiego w Stanach Zjednoczonych Ameryki Północnej z Kościołem katolickim na ziemiach polskich pod zaborami oraz przedstawia działalność duszpasterską jezuitów wśród Polonii amerykańskiej na przełomie XIX i XX w. Więź ta - co ciekawe - została nawiązana już w pierwszym dziesięcioleciu XIX w. dzięki jezuitom z Białej Rusi. Jeden z nich Giovanni Antonio Grassi (1775-1849) dokonał reorganizacji kolegium Georgetown (obecnie znany uniwersytet).

Zawsze czuł się związany z ziemią brzozowską i sanktuarium Matki Miłosierdzia w Starej Wsi k. Brzozowa, przy którym mieści się najstarszy w Towarzystwie Jezusowym nowicjat jezuicki. To właśnie do Starej Wsi k. Brzozowa przyszli w 1820 r. jezuici wypędzeni z cesarstwa rosyjskiego. Osiedlili się w dawnym klasztorze paulińskim, który nie tylko rozbudowali, ale także rozwinęli wszechstronną działalność duszpasterską i kulturalną. O. Grzebień był organizatorem i współorganizatorem kilku konferencji naukowych oraz publikacji poświęconych Starej Wsi i ziemi brzozowskiej. Pod jego redakcją ukazały się książki: Chwalcie z nami Panią Świata. Z dziejów Kościoła na ziemi brzozowskiej, Kraków 1985; Jezuicki ośrodek tajnego nauczania w Starej Wsi, Przemyśl 1989 (współredaktor S. Dydek). Druga publikacja weszła do serii historycznej: „Biblioteka Przemyska".

Udzielał się także jako konferencjonista. Podczas pobytu w Rzymie w lipcu i sierpniu 1988 r. wygłosił na falach Polskiej Sekcji Radia Watykańskiego szereg pogadanek w języku polskim, które przygotował po zapoznaniu się z materiałami archiwalnymi. Pogadanki wpisały się w złoty jubileusz Sekcji Polskiej Radia Watykańskiego oraz ujrzały światło dzienne w bogato ilustrowanej archiwalnymi zdjęciami publikacji pt. Złoty jubileusz Sekcji Polskiej Radia Watykańskiego. Pogadanki radiowe, Roma 1988. Dwa lata później ukazało się drukiem jego obszerne dzieło poświęcone pięćdziesięcioleciu działalności Sekcji Polskiej: Sekcja Polska Radia Watykańskiego. Złoty Jubileusz 1938-1988, Rzym 1990.

Jubilat należy do wielu stowarzyszeń naukowych, Towarzystwa Naukowego KUL (od 1978 r.), Institutum Historicum Societatis Iesu w Rzymie (od 1985 r.), Komitetu Historii Nauki i Techniki Polskiej Akademii Nauk (od 2003 r.), Polskiego Towarzystwa Historyków Edukacji (od 2004 r.). Od 2004 r. jest także członkiem Rady Naukowej Konferencji Episkopatu Polski. Brał również udział w wielu sympozjach i kongresach historycznych w kraju i za granicą ${ }^{38}$.

38 R. Terlecki, Pasja historyka. Ojca Ludwika Grzebienia życie i praca, w: Pamięć wieków ksztaltuje potomność. Księga jubileuszowa dedykowana Księdzu Profesorowi Ludwikowi Grzebieniowi SJ z okazji 70. urodzin, s. 21 . 
Nie ulega wątpliwości, że obok współbraci zakonnych: o. Stanisława Załęskiego, o. Stanisława Bednarskiego, o. Jana Poplatka, o. Bronisława Natońskiego, o. Ludwika Piechnika, ks. Jerzego Paszendy i o. Romana Darowskiego, o. Ludwik Grzebień wpisał się na trwałe do grona wybitnych znawców dziejów Towarzystwa Jezusowego na ziemiach Rzeczypospolitej Obojga Narodów. Do dzisiejszego dnia Jubilat opublikował ponad 1110 prac naukowych, głównie z dziedziny historii Towarzystwa Jezusowego ${ }^{39}$. Ci, którzy znają o. Grzebienia, mają świadomość, że nie powiedział On jeszcze ostatniego słowa, przede wszystkim tego, które najpierw zapisze w komputerze, a następnie odda do druku.

39 „Rocznik Wydziału Filozoficznego Towarzystwa Jezusowego w Krakowie” (1988), s. 175-185; (1993/1994), s. 271-273; (1999), s. 164-169; A. P. Bieś, Bibliografia prac Księdza Profesora Ludwika Grzebienia SJ za lata 1962-2000, w: Jezuicka ars historica. Prace ofiarowane Księdzu Profesorowi Ludwikowi Grzebieniowi SJ, s. 9-42; idem, Bibliografia prac Księdza Profesora Ludwika Grzebienia SJ za lata 19622009, w: Pamięć wieków ksztattuje potomność. Księga jubileuszowa dedykowana Księdzu Profesorowi Ludwikowi Grzebieniowi SJ z okazji 70. urodzin, red. A. P. Bieś, B. Topij-Stempińska, Kraków 2010, s. 33-74. 